\title{
PENGARUH BUDAYA ORGANISASI TERHADAP KINERJA APARATUR NAGARI DALAM PENGELOLAAN KEUANGAN NAGARI DI KABUPATEN TANAH DATAR
}

\author{
THE INFLUENCE OF ORGANIZATIONAL CULTURE ON THE \\ PERFORMANCE OF NAGARI GOVERNMENT APPARATUS IN NAGARI \\ FINANCIAL MANAGEMENT IN TANAH DATAR REGENCY
}

\author{
Mutia Reni ${ }^{1}$ dan Syamsir ${ }^{2}$ \\ ${ }^{1}$ Jurusan Ilmu Administrasi Publik, Fakultas Ilmu Sosial, Universitas Negeri Padang \\ mutiareni32@gmail.com \\ ${ }^{2}$ Jurusan Ilmu Administrasi Publik, Fakultas Ilmu Sosial, Universitas Negeri Padang \\ syamsirsaili@yahoo.com
}

\begin{abstract}
Abstrak
Budaya organisasi merupakan salah satu faktor yang mempengaruhi kinerja pegawai dalam sebuah organisasi, karena budaya organisasi mencerminkan jati diri dan persepsi orang lain dan anggota organisasi mengenai organisasi itu sendiri. Penelitian ini dilatarbelakangai oleh masih kurang baiknya kinerja aparatur nagari dalam pengelolaan keuangan nagari di Kabupaten Tanah Datar. Oleh karena itu tujuan dari penelitian ini adalah untuk menganalisis pengaruh budaya organisasi terhadap kinerja aparatur nagari dalam pengelolaan keuangan nagari. Penelitian ini menggunakan metode penelitian kuantitatif. Penelitian ini dilakukan pada 75 nagari di Kabupaten Tanah Datar dengan total populasi sebanyak 600 responden yang terdiri dari walinagari, sekretaris nagari,bendahara nagari dan lima kepala urusan nagari. Sample pada penelitian ini sebanyak 240 responden dihitung menggunakan rumus slovin. Data dalam penelitian ini dikumpulkan menggunakan kuisioner dengan pengukuran skala likert. Data dalam penelitian ini akan dianalisis menggunakan regresi linear berganda. Hasil penelitian ini menunjukkan bahwa variable budaya organisasi, baik secara simultan ataupun secara parsial, berpengaruh secara signifikan terhadap kinerja pengelolaan keuangan nagari di Kabupaten Tanah Datar.Dari hasil penelitian ini dapat disimpulkan bahwa variabel budaya organisasi baik secara simultan maupun parsial berpengaruh positif terhadap kinerja pengelolaan keuangan nagari di Kabupaten Tanah Datar. oleh karena itu, untuk lebih meningkatkan kinerja aparatur nagari di Kabupaten Tanah Datar disarankan dalam pengelolaan keuangan nagari lebih meningkatkan budaya organisasi, dikarenakan dari beberapa penelitian yang telah dilakukan oleh peneliti lainnya membuktikan bahwa budaya organisasi yang baik akan memberikan dampak yang baik terhadap kinerja pegawai.
\end{abstract}

Keywords: Budaya Organisasi, Kinerja, Pengelolaan Keuangan Nagari

\begin{abstract}
Organizational culture is one of the factors that affect employee performance in an organization. This study was triggered by the persistently poor performance of nagari government apparatus in managing nagari financial in Tanah Datar Regency. Therefore, the purpose of study was to analyze the influence of organizational culture on the performance of nagari government apparatus in managing nagari financial in Tanah Datar Regency.This study applied a quantitative method. This study involved 75 nagari governments in Tanah Datar Regency with total population of 600 people consisting walinagari, nagari secretary, nagari treasurer, and five head of nagari affairs. The sample in this study was 248
\end{abstract}


respondents, determined using slovin formula. The data of this study were collected through spreading questionnaire with a likert scale measurement. Data of this studi were analyzed with Multiple Linear Regression Test. The result in this study showed that organization culture variable, both simultaneously and partially significantly influences the nagari financial management in Tanah Datar Regency. Therefore, in order to improve the performance of nagari government apparatus in Tanah Datar Regency, it is recommended to pay more attention and improve the development of organizational culture, because it was found out from previous research that a developed organizational culture results in a positive impact on employee performance.

Keywords: organizational culture, job performance, nagari financial management

\section{PENDAHULUAN}

Pada saat ini pemerintahan daerah telah diberikan kewenangan untuk mengelola dan memanfaatkan potensi yang ada di daerah masing-masing untuk dikelola dan dimanfaatkan demi meningkatkan kesejahteraan masyarakat daerah dan meningkatkan kesetaraan pada setiap daerah yang ada di indonesia. Pembahasan mengenai dana yang digunakan oleh setiap daerah untuk pembiayaan kegiatan daerah yang merupakan salah satu rencana kegiatan tahunan pemerintah yang diatur dalam UndangUndang Nomor 32 Tahun 2004 membahas mengenai pemerintahan daerah menjelaskan bahwa setiap anggaran pendapatan belanja daerah ditetapkan oleh perundang-undangan. Dijelaskan juga bahwa setiap daerah mempunyai kesempatan untuk mengelola pendapatan dan keuangan daerah masingmasing. Hal ini bertujuan untuk meningkatkan kemandirian dan mempercepat laju pertumbuhan disetiap daerah. Pemberian kesempatan terhadap pemerintahan daerah untuk mengelola daerahnya sendiri adalah salah satu bentuk pelaksanaan sistem desentralisasi. Dimana desentralisasi memiliki tujuan untuk mempercepat laju pertumbuhan dengan mengharapkan adanya partisipasi masyarakat untuk ikut serta dalam memajukan daerahnya.

Selain itu semenjak disahkannya Undang-Undang Nomor 6 Tahun 2014 Tantang Desa, menjelaskan bahwa desa memperoleh kesempatan yang luas untuk mengurus pemerintahannya sendiri dan mengelola proses keberlangsungan pembangunan desanya masing-masing yang bertujuan untuk meningkatkan taraf kehidupan masyarakat desa. Dengan adanya peraturan ini pemerintahan desa dituntut untuk mandiri dalam mengelola sumber daya yang dimilikinya termasuk hal yang berhubungan dengan pengelolaan keuangan dan kekayaan desa yang dimiliki. Selanjutnya, dalam Peraturan Mentri Dalam Negeri Nomor 113 Tahun 2014 tentang Pengelolaan Keuangan Desa, dijelaskan bahwa pengelolaan keuangan 
desa merupakan bentuk kegiatan yang terdiri dari perencanaan, pelaksanaan, pelaporan, dan pertanggungjawaban dalam penggunaan dana yang diberikan kepada desa. Peraturan tersebut juga menjelaskan bahwa pengelolaan dana desa harus dikelola sesuai dengan asas-asas yang disebutkan dalam peraturan ini diantaranya yaitu; transparansi, akuntabilitas, partisipatif, dan dilaksanakan dengan tertib dan disiplin anggaran.

\section{Selanjutnya Peraturan Pemerintah}

Nomor 43 Tahun 2014 juga menjelaskan mengenai pengelolaan keuangan desa. Dijelaskan dalam peraturan ini bahwa proses pengelolaan keuangan desa dimulai dari perencanaan, pelaksanaan, penatausahaan, pelaporan serta pertanggungjawaban. Dalam peraturan ini dijelaskan bahwa pemerintahan daerah mengalokasikan anggaran minimal 10\% dari dana perimbangan yang diberikan kepada kabupaten dari anggaran pendapatan belanja daerah setelah dikurangi dana alokasi khusus. Dari dana yang diperoleh desa digunakan paling sedikit $70 \%$ untuk pembiayaan pelaksanaan pemerintah desa, pembinaan kemasyarakatan desa, serta pemberdayaan masyarakat desa. Kemudian dari dana yang diterima oleh desa tersebut digunakan paling banyak $30 \%$ digunakan untuk penghasilan tetap dan tunjangan kepala desa dan perangkat desa, biaya operasional pemerintah desa, tunjangan dan operasional badan pemusyawaratan desa, insentif rukun tetangga dan rukun warga. Nagari merupakan salah satu bentuk desa adat yang ada di Indonesia dimana negara mendukung setiap pemerintahan yang bersifat khusus. Hal tersebut dijelaskan dalam Undang-Undang Nomor 18b Tahun 1945. Nagari itu sendiri merupakan salah satu bentuk desa adat yang ada di Minang Kabau.

Dalam Peraturan Menteri Dalam Negeri Nomor 37 Tahun 2007 tentang Pedoman Pengelolaan Keuangan Desa dijelaskan bahwa Penggunaan Dana Desa didasarkan pada skala prioritas yang ditetapkan pada tingkat desa. Penggunaan ADD dibagi menjadi 2 (dua) yaitu untuk belanja aparatur dan operasional pemerintahan desa serta untuk biaya pemberdayaan masyarakat. Rincian penggunaan anggaran dana desa sebagai berikut;

1) Belanja aparatur dan operasional pemerintahan desa sebesar 30\% (tiga puluh perseratus) dari total keseluruhan ADD yang digunakan sebagai berikut:

a. Operasional Pemerintah Desa sebesar 50 $\%$ (lima puluh perseratus) dari belanja Aparatur dan Operasional Pemerintahan desa yang digunakan untuk :

(1) Belanja barang danjasa Pembelian/pengadaan barang, belanja pemeliharaan sarana Pemerintah Desa, belanja perjalanan dinas kepala desa dan perangkat desa sebesar $40 \%$ 
(empat puluh perseratus) dari

Operasional Pemerintah Desa dan,

(2) Belanja pegawai sebesar 60\% (enam puluh perseratus) dari Operasional Pemerintah Desa untuk honor tim pelaksana desa. Operasional BPD sebesar 25\% (dua puluh lima perseratus) dari Belanja pemerintahan desa dengan perincian sebagai berikut :

(3) Belanja Barang dan Jasa sebesar 40 $\%$ (empat puluh perseratus) dari total operasional BPD yang digunakan untuk pembelian / pengadaan barang, belanja pemeliharaan sarana sekretariat BPD, belanja perjalanan dinas Ketua dan Anggota BPD.

(4) Belanja pegawai sebesar $60 \%$ (enam puluh perseratus) dari Operasional BPD yang digunakan untuk tunjangan Pimpinan dan Anggota BPD.

(5) Tunjangan Kesejahteraan Aparatur Pemerintah Desa sebesar 25\% (dua puluh lima perseratus) dari belanja Pemerintah Desa.

2)Pemberdayaan masyarakat $70 \%$ (tujuh puluh perseratus) dari total keseluruhan ADD dengan perincian sebagai berikut :

a) Belanja modal (publik) sebesar $70 \%$ (tujuh puluh perseratus) dari belanja Pemberdayaan Masyarakat dengan perincian sebagai berikut ;
(1) Biaya perbaikan prasarana dan sarana publik;

(2) Penyertaan modal usaha masyarakat melalui BUM Desa;

(3) Biaya untuk pengadaan ketahanan pangan;

(4) Perbaikan lingkungan dan pemukiman;

(5) Tehnologi tepat guna;

(6) Perbaikan kesehatan dan pendidikan;

(7) Pengembangan sosial budaya; dan/atau

(8) Kegiatan lainnya yang dianggap penting.

b) Penguatan Kapasitas Lembaga Kemasyarakatan sebesar $30 \%$ (tiga puluh perseratus) dari belanja Pemberdayaan Masyarakat, yang digunakan untuk Belanja barang dan Jasa; Belanja Pegawai yang meliputi;

(1)Penunjang kegiatan PKK sebesar Rp.5.000.000,- (lima juta rupiah);

(2) Penunjang kegiatan LPMD;

(3) Penunjang kegiatan RT/RW;

(4) Penunjang kegiatan Karang Taruna, dan/atau

(5) Penunjang kegiatan Hansip

b. Untuk Ploting/pembagian besaran dana ADD yang digunakan untuk tunjangan Perangkat Desa, Honor Bendahara Desa dan Penguatan Kapasitas Lembaga 
Kemasyarakatan selain penunjang kegiatan PKK, diserahkan sepenuhnya pada masing-masing desa sesuai dengan rencana kegiatan selama satu tahun anggaran dan dimasukkan dalam APB Desa yang ditetapkan dengan Peraturan Desa.

Selanjutnya, Peraturan Bupati Tanah Datar Nomor 11 Tahun 2014 tentang Pedoman Pengelolaan Keuangan Nagari menjelaskan bahwa keuangan nagari dikelola atas dasar peraturan perundang-undangan dan dikatakan bahwa setiap belanja daerah yang diatasnamakan nagari harus memiliki bukti yang sah. Pengelolaan keuangan nagari seperti yang dijelaskan dalam peraturan ini dikelola dalam kurun waktu 1 tahun yang dihitung dari tanggal 1 Januari hingga 30 Desember atau sering juga disebut dengan tahun anggaran. Dalam peraturan ini dapat dilihat bahwa pengelolaan keuangan nagari di Kabupaten Tanah Datar dikelola secara disiplin dan transparan. Selain itu setiap pengeluaran yang terjadi harus memiliki bukti yang sah. Namun pada kenyataannya masih ditemukan adanya pelanggaran-pelanggaran atau penyimpangan mengenai pengelolaan keuangan nagari di Kabupaten Tanah Datar.

Salah satu bentuk penyimpangan yang terjadi adalah adanya Walinagari pada salah satu kenagarian yang ada di Kabupaten Tanah Datar melakukan tindak pidana korupsi, seperti
WalinagariLimo Kaum yang melakukan korupsi dalam penggunaan dana reward lomba nagari berprestasi baik tingkat kabupaten, provinsi maupun nasional yang merugikan negara RP. 94,2 juta yang diungkapkan oleh Kepala Kejari Batu Sangkar M. Fatria di Batusangkar. Penyelewengan yang dilakukan oleh mantan WalinagariLimo Kaum telah melanggar Peraturan Bupati Tanah Datar mengenai pengelolaan keuangan daerah (Wahyu, 2016)

Permasalahan lainnya yang membahas hal yang hampir serupa diantaranya yaitu dugaan penyalahgunaan dana proyek abal-abal di Nagari Sungai Tarab. Tepatnya di Jorong Koto Panjang Nagari Sungai Tarab, Kecamatan Sungai Tarab Kabupaten Tanah Datar.Jenis kegiatan berupa pengecoran jalan Piliang, dalam kegiatan tersebut diduga kuat adanya indikasi korupsi dengan pekerjaan proyek asal jadi. Hal tersebut terlihat dari adanya penyimpangan spesifikasi pekerjaan dalam proyek jalan tersebut. Menurut Kaur Pembangunan Nagari Sungai Tarab, Hamzah, proyek jalan tersebut merupakan tanggung jawab dari TPK (Tim Pelaksana Kegiatan). Sedangkan speknya seperti ketebalan dari rabat beton yang dikerjakan sudah sesuai. Namun kenyataannya pernyataan tersebut sangat tidak sesuai dengan apa yang di temukan di lapangan. Dalam kasus yang sama pada proyek pengecoran jalan Piliang Ganjak, 
Jorong Koto Panjang juga mengalami hal yang sama. Namun Walinagari Sungai Tarab, M. Rizal mengatakan bahwa dalam pengerjaan proyek jalan tersebut sudah selesai dan tidak ada masalah dan juga sudah sesuai dengan ketentuan yang berlaku. Pernyataan Walinagari tersebut nyatanya juga tidak sesuai dengan apa yang di temukan di lapangan. (Dwi, 2017)

Selain itu melalui wawancara yang dilaksanakan pada hari Selasa,15 Mei 2018 dengan WalinagariTigo Koto Kecamatan Rambatan mengatakan bahwa unsur-unsur walinagari terutama di Nagari Tigo Koto tidak adanya tupoksi yang jelas. Dimana tupoksinya sudah ada akan tetapi mereka tidak bisa menjabarkan fungsi tersebut. Perangkat nagari sudah diberikan pembekalan dan sebagainya, akan tetapi sepertinya perangkat nagari tidak diberikan tugas dengan pekerjaan yang dilatih tersebut. sehingga perangkat nagari yang mampu bekerja hanya bendahara nagari, sehingga ketika terjadinya pertukaran bendahara, perangkat nagari yang ada tidak mampu bekerja sehingga karena kekurangan ilmu mereka harus belajar ke nagari tetangga. Disamping itu Kaur Perekonomian Nagari Padang Magek Kecamatan Rambatan dalam wawancara yang dilakukan pada tanggal yang sama mengatakan bahwa masih adanya pengelompok-pengelompokkan perangkat nagari dalam menyelesaikan pekerjaanya.
Selain itu dalam melaksanakan pekerjaan pengelolaan keuangan nagari perangkat nagari tidak bekerja dengan solid.Masalah lainnya disampaikan oleh Walinagari Pandai Sikek Kecamatan X Koto mengatakan bahwa kinerja perangkat di Kenagarian Pandai Sikek lebih mengutamakan dokumentasi dari pada hasil.

Dari permasalahan yang telah dijelaskan dapat dilihat bahwa masih adanya dugaan penyimpangan terhadap alokasi dana nagari yang disebabkan karena kurang baiknya kinerja pengelolaan keuangan nagari yang dilakukan oleh aparatur nagari di Kabupaten Tanah Datar, yang dapat dilihat dari masih kurangnya transparansi dalam pengelolaan keuangan dibeberapa nagari di Kabupaten Tanah Datar. Selain itu, budaya organisasi di Pemerintahan Nagari di Kabupaten Tanah Datar masih kurang baik. Dimana budaya organisasi itu sendiri merupakan nilai, norma, keyakinan, filsafat, kebiasaan organisasi, dan lainnya yang dipelihara dalam jangka waktu lama yang dilakukan oleh pendiri dan anggota-anggota kelompok di dalam organisasi, yang kemudian akan diwariskan dan diajarkan kepada anggota baru dalam organisasi kemudian diterapkan pada setiap kegiatan organisasi yang pada akhirnya berdampak padacaraberfikir, sikap, dan perilaku anggota organisasi dalam memproduksi produk, memberikan pelayanan, 
dan mencapai tujuan organisasi

(Wiraman,2007).

Selanjutnya dilihat dari penelitian terdahulu yang penulis temukan terdapat penelitian yang menyatakan adanya pengaruh yang signifikan antara budaya organisasi terhadap kinerja. Dimana penelitian yang telah dilaksanakan oleh Baba (2012) yang melakukan penelitian Pengaruh Kompetensi, Komunikasi, dan Budaya Organisasi Terhadap Kinerja Karyawan (Studi kasus PT. Semen Bosowa Maros), Dimana dalam penelitian ini dikatakan bahwa budaya organisasi akan menciptakan latar belakang yang berhubungan dengan lingkungan, cara kerja, sikap, perilaku, dan pandangan karyawan terhadap organisasi dimana mereka berada. Hartidah \& Ludigdo (2010) yang melakukan penelitian terhadap Pengaruh Budaya Organisasi Terhadap Kinerja Auditor, dimana dari hasil penelitiannya ditemukan bahwa budaya organisasi memiliki dampak yang signifikan terhadap kinerja aouditor. Maabuat (2016) melakukan penelitian terhadap Pengaruh Kepemimpinan, Orientasi Kerja, Dan Budaya Organisasi Terhadap Kinerja Pegawai, yang menyatakan bahwa budaya organisasi jika diuji secara sendiri-sendiri menunjukkan bahwa tidak terdapat pengaruh yang signifikan terhadap kinerja pegawai di Dispenda Sulut UPTD Tondano.
Dari penjabaran masalah yang penulis paparkan di atas, penulis tertarik melakukan penelitian tentang pengaruh budaya organisasi terhadap kinerja aparatur nagari dalam pengelolaan keuangan nagari di Kabupaten Tanah Datar. Penelitian ini merupakan inti sari dari hasil penelitian skripsi dan merupakan bagian dari penelitian payung yang dilakukan oleh Syamsir (2017) dengan judul Model Pembinaan Aparatur Pemerintahan Nagari dalam Pengelolaan Keuangan Nagari di Kabupaten Tanah Datar. Penelitian ini bertujuan untuk ; Mengetahui pengaruh budaya organisasi terhadap kinerja aparatur nagari dalam pengelolaan keuangan nagari di Kabupaten Tanah Datar. (2) Mengetahui pengaruh inovasi dan pengambilan resiko terhadap kinerja aparatur nagari dalam pengelolaan keuangan nagari di Kabupaten Tanah Datar (3) Mengetahui pengaruh orientasi hasil terhadap kinerja aparatur nagari dalam pengelolaan keuangan nagari di Kabupaten Tanah Datar (4) Mengetahui pengaruh orientasi orang terhadap kinerja aparatur nagari dalam pengelolaan keuangan nagari di Kabupaten Tanah Datar (5) Mengetahui pengaruh orientasi tim terhadap kinerja aparatur nagari dalam pengelolaan keuangan nagari di Kabupaten Tanah Datar (6) Mengetahui pengaruh keagresifan terhadap kinerja aparatur nagari dalam pengelolaan 
keuangan nagari di Kabupaten Tanah Datar

Mengetahui

pengaruh

kemantapan/stabilitas terhadap kinerja aparatur nagari dalam pengelolaan keuangan nagari di Kabupaten Tanah Datar.

\section{METODE PENELITIAN}

Penelitian ini adalah penelitian kuantitatif. Penelitian dilaksanakan dibeberapa kenagarian di Kabupaten Tanah Datar Provinsi Sumatera Barat. Penelitian dilakukan dalam jangka waktu kurang lebih 3 (tiga) bulan. Penelitian ini memiliki populasi sebanyak 600 orang responden dengan jumlah nagari sebanyak 75 nagari. Responden dalam penelitian ini terdiri dari semua aparatur nagari yang ada di Kabupaten Tanah Datar yang terdiri dari walinagari, sekretaris nagari, bendahara nagari dan 5 kaur nagari (pemerintahan, ekonomi, umum, pembangunan dan kesejahteraan rakyat). Sampel yang digunakan pada penelitian ini sebanyak 248 responden yang dihitung menggunakan rumus Slovin. Dalam pengambilan sample digunakan teknik Multistage Random Sampling yang merupakan pengambilan sampel dari populasi yang dilakukan secara bertingkat dan didasarkan atas pembagian wilayah kerja pada suatu pemerintahan.

Pengumpulan data pada penelitian ini dilakukan dengan melakukan penyebaran kuesioner dengan pengukuran skala Likert dengan empat opsi, diantaranya yaitu: Sangat Setuju, Setuju, Tidak Setuju, Sangat Tidak Setuju. Kemudian Data yang diperoleh dianalisis menggunakan uji Regresi Linear Berganda. Sebelum itu dilakukan uji Asumsi Klasik. Dimana uji asumsi klasik merupakan syarat untuk dilakukan Uji Regresi. Kemudian untuk memperoleh gambaran umum dari kedua variable digunakan Frekuensi, Mean, dan TCR.

Pada penelitian ini untuk mengukur kinerja dalam pengelolaan keuangan desa, penulis menggunakan indikator yang dikemukakan oleh Murtiono (2016) sebagai berikut: (1) Transparan, artinya prinsip keterbukaan yang memukinkan masyarakat untuk mengetahui dan mendapatkan akses informasi seluasnya tentang pengelolaan keuangan desa atau APB Desa. Akuntabel, artinya prinsip dari kewajiban seseorang untuk mempertanggungjawabkan pengelolaan dan pengendalian sumber daya dan pelaksanaan dan kebijakan yang dipercayakan kepadanya dalam rangka pencapaian tujuan yang telah ditetapkan. (3) Partisipatif, artinya bahwa pengelolaan keuangan desa harus memberikan ruang seluas-luasnya kepada masyarakat secara aktif terlibat dalam setiap tahapan proses pengelolaan keuangan desa. (4) Tertib dan disiplinanggaran, yaitu mengandung makna 
APBDesa harus dikelola secara tepat waktu dan tepat guna yang didukung dengan buktibukti administrasi yang dapat dipertanggungjawabkan serta berpedoman pada peraturan yang berlaku.

Selanjutnya untuk mengukur pengaruh budaya organisasi terhadap kinerja aparatur nagari dalam pengelolaan keuangan nagari di Kabupaten Tanah Datar peneliti menggunakan indicator budaya organisasi yang dikemukakan oleh Veithzal Rivai dan Deddy Mulyadi (2013), yaitu: (1) Inovasi dan pengambilan resiko,yaitu kadar seberapa jauh anggota dalam organisasi didorong untuk lebih inovatif dan kemampuannya dalam mengambil resiko. (2) Orientasi hasil, yaitu seberapa jauh pimpinan berfokus pada hasil atau output dan bukannya pada cara mencapai hasil itu. (3) Orientasi orang, yaitu seberapa jauh keputusan manajemen dalam ikut turut mempengaruhi orang-orang yang ada dalam organisasi (4) Orientasi tim, yaitu seberapajauh pekerjaan yang disusun berdasarkan oleh anggota tim dan bukannya perorangan atau individu. (5) Keagresifan, yaitu sejauh mana kemampuan karyawan dalam bersikap agresif dan mampu bersaing dari pada bekerjasama. (6) Kemantapan atau stabilitasya itu kadar seberapa jauh suatu keputusan dan tindakan suatu organisasi dalam menekankan status quo.

\section{HASIL PENELITIAN}

Seperti yang telah dijelaskan sebelumnya penelitian ini bertujuan untuk mengetahui apakah terdapat pengaruh budaya organisasi terhadap kinerja aparatur nagari pada pengelolaan keuangan nagari di Kabupaten Ta nah Datar dengan sub-variabel inovasi dan pengambilan resiko, orientasi hasil, orientasi orang, orientasi tim, keagresifan, dan kemantapan/stabilitas. Untuk menjawab pertanyaan penelitian ini dapat dilihat melalui hasil analisis pengolahan data berdasarkan temuan dilapangan yang ada di bawahini;

Tabel 1. Pengaruh variable budaya organisasi (secara simultan) terhadap kinerja aparatur nagari dalam pengelolaan keuangan

\begin{tabular}{|c|c|c|c|c|c|}
\hline \multicolumn{6}{|c|}{ Model Summary ${ }^{b}$} \\
\hline Model & $\mathbf{R}$ & $\begin{array}{c}\mathbf{R} \\
\text { Square }\end{array}$ & $\begin{array}{l}\text { Adjusted } \\
\text { R Square }\end{array}$ & $\begin{array}{l}\text { Std. } \\
\text { Error of } \\
\text { the } \\
\text { Estimate }\end{array}$ & $\begin{array}{l}\text { Durbi } \\
\text { n- } \\
\text { Watso } \\
\text { n }\end{array}$ \\
\hline 1 & $.505^{\mathrm{a}}$ & .255 & .233 & .30370 & 1.778 \\
\hline \multicolumn{6}{|c|}{$\begin{array}{l}\text { a. Predictors: (Constant), Inovasi dan PengambilanResiko, } \\
\text { Orientasi Tim, Kemantapan/Stabilitas, Orientasi Orang, } \\
\text { Orientasi Hasil, Keagresifan }\end{array}$} \\
\hline $\begin{array}{l}\text { b. Depen } \\
\text { Pengelola }\end{array}$ & $\begin{array}{l}\text { ent Var } \\
\text { inKeua }\end{array}$ & able: Rata- & -Rata & & \\
\hline
\end{tabular}

Dari Tabel 1 dapat dijelaskan bahwa Adjusted $R$ Square dari hasil analisis uji regresi adalah 0,233 . Dengan demikian biasa disimpulkan bahwa besarnya pengaruh budaya organisasi dengan variable inovasi dan pengambilan 
resiko, orientasi hasil, orientasi orang, orientasi tim, keagresifan, dan kemantapan/stabilitas terhadap kinerja aparatur nagari dalam pengelolaan keuangan nagari sebesar 23,3\%. Selebihnya sebesar $76,7 \%$ dipengaruhi oleh variabel lain di luar peneltian ini.

Selanjutnya, untuk menjawab rumusan masalah lainnya yang ingin dijawab diantaranya yaitu, apakah terdapat pengaruh inovasi dan pengambilan resiko, orientasi hasil, orientasi orang, orientasi tim,keagresifan, kemantapan/stabilitas dapat dilihat pada Tabel 2 yang telah disajikan di bawah ini.

Tabel 2. Pengaruh variable inovasi dan pengambilan resiko, orientasi hasil, orientasi tim, keagresifan, dan kemantapan/stabilitas secara sendirisendiri terhadap pengelolaan keuangan nagari

\begin{tabular}{lcccc}
\hline Variabel & $\mathbf{R}$ & $\begin{array}{c}\mathbf{R} \\
\text { Square }\end{array}$ & $\begin{array}{c}\text { Adjuste } \\
\mathbf{d ~ r ~} \\
\text { Square }\end{array}$ & Sig. \\
\hline $\begin{array}{l}\text { Pengambilanre } \\
\text { siko }\end{array}$ & $.293^{\mathrm{a}}$ & .086 & .082 & $.000^{\mathrm{b}}$ \\
Inovasi & $.307^{\mathrm{a}}$ & .094 & .091 & $.000^{\mathrm{b}}$ \\
Orientasihasil & $.448^{\mathrm{a}}$ & .201 & .198 & $.000^{\mathrm{b}}$ \\
Orientasi orang & $.302^{\mathrm{a}}$ & .091 & .088 & $.000^{\mathrm{b}}$ \\
Orientasitim & $.214^{\mathrm{a}}$ & .046 & .042 & $.001^{\mathrm{b}}$ \\
Keagresifan & $.233^{\mathrm{a}}$ & .054 & .051 & $.000^{\mathrm{b}}$ \\
$\begin{array}{l}\text { Kemantapan/st } \\
\text { abilitas }\end{array}$ & $.290^{\mathrm{a}}$ & .084 & .080 & $.000^{\mathrm{b}}$ \\
\hline
\end{tabular}

Berdasarkan Tabel 2 dapat dilihat bahwa variable pengambilan resiko memiliki angka Adjusted $R$ Square 0,082. Dapat dijelaskan bahwa pengaruh pengambilan resiko terhadap kinerja pengelolaan keuangan nagari di Kabupaten Tanah Datar sebesar 8,2 $\%$ dan sisanya sebanyak $91,8 \%$ dipengaruhi oleh variabel lain yang tidak diteliti dalam penelitian ini. Sub variabel inovasi memiliki Adjusted $R$ Square sebesar 0,091 dapat disimpulkan bahwa pengaruh inovasi terhadap kinerja pengelolaan keuangan nagari di Kabupaten Tanah Datar sebesar 9,1\% dan 90,9\% lainnya dipengaruhi oleh variabel lain yang tidak diteliti di dalam penelitian ini. Sub variabel orientasi hasil memiliki Adjusted $R$ Square sebesar 0,198 dapat dijelaskan bahwa pengaruh orientasi hasil terhadap pengelolaan keuangan nagari di Kabupaten Tanah Datar sebesar 19,8\% dan sisanya sebanyak 80,2\% dipengaruhi oleh variabel lain yang tidak diteliti di dalam penelitian ini. Variable orientasi orang memiliki Adjusted $R$ Square sebesar 0,088 dapat dijelaskan bahwa pengaruh orientasi orang terhadap pengelolaan keuangan nagari di Kabupaten Tanah Datar sebesar $8,8 \%$ dan sebanyak $91.2 \%$ lainnya dipengaruhi oleh variable lain. Sub variable orientasi tim memiliki Adjusted $R$ Square 0,042 dapat disimpulkan bahwa pengaruh orientasi tim terhadap pengelolaan keuangan nagari sebesar 4,2\% dan sebanyak 95,8\% dipengaruhi oleh variable lain. Variabel keagresifan memiliki Adjusted $R$ Square 0,051 dapat disimpulkan bahwa pengaruh 
keagresifan terhadap pengelolaan keuangan nagari sebesar $5,1 \%$ dan $94,9 \%$ dipengaruhi oleh variable lain. Variable kemantapan/stabilitas memiliki Adjusted $R$ Square 0,080 yang berarti bahwa pengaruh kemantapan/stabilitas terhadap pengelolaan keuangan nagari sebesar $8 \%$ dan $92 \%$ lainnya dipengaruhi oleh variable selain variabel yang digunakan dalam penelitian ini.

Selain itu juga dapat dilihat pada table 2 di atas bahwa taraf signifikansi sub variable inovasi dan pengambilan resiko, orientasi hasil, orientasi orang, keagresifan, kemantapan/stabilitas memiliki taraf signifikansi menunjukkan angka 0,000a Sedangkan untuk variable orientasi tim taraf signifikansi menunjukkan angka 0,001 a . Dari hasil pengolahan data pada uji regresi yang dilakukan dapat dilihat bahwa nilai signifikansi lebih kecil dari batas signifikansi 0,05 yang berarti Ho ditolak dan Ha diterima, sehingga dapat disimpulkan bahwa pengaruh budaya organisasi terhadap kinerja aparatur nagari dalam pengelolaan keuangan nagari di Kabupaten Tanah Datar dapat dipercaya hingga $100 \%$.

Dari hasil temuan, peneliti telah memaparkan mengenai pengaruh budaya organisasi terhadap kinerja aparatur nagari dalam pengelolaan keuangan nagari di Kabupaten Tanah Datar. Setelah melakukan penelitian dan kemudian dilakukan penganalisisan data, dari hasil analisis tersebut membuktikan bahwa budaya organisasi memiliki pengaruh yang signifikan baik secara bersama-sama (simultan) maupun secara sendiri-sendiri (parsial) terhadap kinerja aparatur nagari dalam pengelolaan keuangan nagari dengan nilai signifikansi kecil dari 0,05 yang berarti bahwa Ho ditolak dan Ha diterima.

\section{PEMBAHASAN}

Hasil penelitian mengenai pengaruh budaya organisasi terhadap kinerja aparatur nagari dalam pengelolaan keuangan nagari di Kabupaten Tanah Datar telah membuktikan adanya pengaruh budaya organisasi terhadap kinerja aparatur nagari dalam pengelolaan keuangan nagari, baik secara simultan maupun sendiri-sendiri.

Dengan melihat hasil penelitian ini dapat dipahami hasil penelitian ikut memperkuat teori yang telah ada, sebagaimana yang dikemukakan oleh Robbins (dalam Sopiah, 2008) yang mengatakan bahwa budaya organisasi merupakan suatu nilai dominan yang didukung oleh suatu organisasi, sebagai falsafah yang menuntun kebijaksanaan organisasi terhadap pegawai dan konsumen, sebagai suatu cara pekerjaan yang dilakukan ditempat tersebut yang menjadi anggapan dankepercayaan dasar yang terdapat diantara anggota-anggota organisasi. Teori ini 
menjelaskan bahwa budaya organisasi menjadi suatu nilai yang mendasar dalam organisasi yang kemudian akan mempengaruhi bagaimana setiap anggota organisasi dalam menyelesaikan pekerjaannya.

Selain itu penelitian ini juga mendukung teori yang dikemukakan oleh Timpe (dalam Syamsir, 2013) yang mengatakan bahwa ada dua dimensi yang mempengaruhi kinerja dimana salah satunya adalah dimensi external yang terdiri dari lingkungan sosial seperti perilaku, sikap, dan tindakan rekan kerja, bawahan atau pimpinan, fasilitas kerja dan iklim organisasi. Pada teori ini menjelaskan bahwa kinerja dipengaruhi oleh perilaku dan sikap anggota dalam organisasi. Sebagaimana yang diketahui bahwa sikap dan perilaku anggota organisasi juga dipengaruhi oleh budaya yang ada di dalam organisasi itu sendiri.

Selain itu penelitian ini juga mendukung teori yang dikemukakan dalam Edison (2016) yang menyatakan bahwa budaya organisasi merupakan pola dari keyakinan, perilaku, asumsi, dan nilai-nilai yang dimiliki bersama. Budaya organisasi membentuk cara berperilaku dan berinteraksi dengan sesama anggota organisasi dan mempengaruhi cara kerja mereka. Selain itu Edison (2016) juga menjelaskan bahwa untuk menunjang kinerja, sangat diperlukan budaya organisasi yang kontruktif atau kuat, untuk mencapai itu perlu pemenuhan-pemenuhan diantaranta kesadaran diri, keagresifan, kepribadian, peforma, dan orientasi tim. Selain itu dikatakan bahwa budaya organisasi adalah sekelompok asumsi penting yang dipegang bersama oleh anggota-anggota suatu organisasi. Asumsi yang dimiliki bersama oleh anggota organisasi ini pada akhirnya akan mempengaruhi pendapat dan tindakan dalam organisasi.

Penelitian ini juga mendukung teori yang dikemukakan oleh Wheelen dan Hunger (dalam Sopiah, 2008) bahwa budaya organisasi akan membantu dalam pengembangan jati diri pegawai, mengembangkan hubungan antara pribadi pegawai dengan organisasi, membantu dalam stabilitas organisasi dan menyediakan pedoman perilaku yang merupakan hasil dari norma perilaku yang telah dibentuk. Teori ini menjelaskan bahwa setiap sikap dan perilaku anggota organisasi merupakan suatu hal yang dibentuk dari dalam organisasi itu sendiri yang pada akhirnya akan mempengaruhi terhadap cara anggota organisasi menyelesaikan pekerjaannya.

Hasil penelitian ini juga membuktikan teori yang dikemukakan oleh Borner (dalam Sopiah, 2008) menyatakan bahwa terdapat tiga variabel yang dapat mempengaruhi kinerja yaitu: (1) Variabel orang termasuk 
atribut yang dimiliki seseorang sebelum melakukan tugas seperti kontern pengetahuan, pengetahuan organisasi, kemampuan, kepercayaandiri, gaya kognitif, motivasi instrinsik, dan nilai-nilai budaya. (2) Variabel tugas termasuk faktor-faktor yang bervariasi baik di dalam maupun di luar tugas, seperti kompleksitas, format presentasi, pengolahan dan respon modus siaga. (3) Variabel lingkungan meliputi semua kondisi keadaan, dan pengaruh di sekitar orang yang melakukan tugas tertentu, seperti tekanan waktu, akuntabilitas, tujuan yang telah ditetapkan dan umpan balik.

Selanjutnya penelitian ini juga mendukung teori yang dikemukakan dalam dalam Tika (2010) yang mengatakan bahwa budaya merupakan suatu system pembagian nilai dan kepercayaan yang berinteraksi terhadap anggota yang berada dalam suatu organisasi, struktur organisasi, dan system kontrol yang akan melahirkan norma-norma perilaku. Pengertian lainnya yang dikemukakan dalam buku Tika (2010) yang sama mengatakan bahwa budaya merupakan pola asumsi dasar yang diciptakan, ditemukan, atau dikembangkan oleh kelompok tertentu sebagai suatu pembelajaran untuk mengatasi masalah adaptasi eksternal dan integrasi internal yang legal dan terlaksakan dengan baik dan oleh karena itu budaya diwariskan kepada anggota yang baru untuk dijadikan sebagai cara yang tepat untuk memahami, memikiran, dan merasakan terkait dengan masalah-masalah tersebut. Ada beberapa unsur dalam budaya dimana diantaranya yaitu; ilmu pengetahuan, seni, moral, hukum, adatistiadat, perilaku atau kebiasaan (norma) dalam masyarakat, asumsi-asumsi dasar, system nilai, pembelajaran/ pewarisan.

Selanjutnya penelitian ini juga mendukung teori yang dikemukakan oleh Wiraman (2007) yang menyatakan bahwa peran budaya organisasi terhadap organisasi, anggota organisasi dan mereka yang berhubungan dengan organisasi, yaitu; 1) Identitas Organisasi, Budaya organisasi memiliki karakteristik yang menggambarkan identitas organisasi dan membedakannya dengan organisasi lain. 2) Menyatukan Organisasi, Budaya organisasi merupakan lem normatif yang menyatukan unsur-unsur organisasi menjadi satu. 3) Reduksi Konflik, Dalam budaya organisasi yang demokratis musyawarah mufakat atau voting merupakan cara untuk menyelesaikan perbedaan atau konflik. 4) Komitmen kepada organisasi dan kelompok, Budaya organisasi tidak hanya menyatukan tetapi juga memfasilitasi komitmen anggota organisasi pada organisasi dan kelompok kerjanya. 5) Reduksi Tidakpastian, Budaya organisasi mengurangi ketidakpastian dan meningkatkan kepastian 
dalam melaksanakan tugas dan fungsinya. 6) Menciptakan konsistensi, motivasi, meningkatkan kinerja organisasi, dan merupakan salah satu sumber kompetitif dalam organisasi.

Selanjutnya penelitian ini mendukung penelitian yang dilakukan oleh Hodge dan Anthony (dalam Sopiah, 2008) yang menemukan bahwa budaya organisasi memberikan pengaruh yang positif terhadap kinerja karyawan. Suatu budaya yang kuatakan terlihat dari adanya kesepakatan yang tinggi dikalangan pegawai terhadap apa yang harus dipertahankan oleh organisasi, dan mengurangi kecenderungan pegawai untuk meninggalkan organisasi.

Selain itu penelitian ini juga mendukung teori Sutrisno (dalam Dewi, 2013) menyatakan bahwa budaya organisasi merupakan perangkat system nilai, keyakinan atau norma yang sudah lama berlaku dan disepakati bersama oleh kelompok organisasi sebagai pedoman dalam berperilaku dan pemecahan masalah-masalah organisasi. Dari penjelasan tersebut dapat dilihat bahwa suatu budaya organisasi memiliki peran terhadap kinerja anggota organisasi dimana budaya organisasi merupakan suatu alat perekat yang mengikat seluruh komponen organisasi, menentukan identitas dan sebagai motivator dan bisa dijadikan pedoman bagian aggota organisasi. Dalam sebuah organisasi budaya organisasi akan menjadi perekat yang membuat para anggota organisasi menjadi lebih dekat dan dapat mengarahkan perkembangan organisasi kearah yang lebih baik.

Penelitian ini juga mendukung teori lainnya seperti teori yang dikemukakan oleh Fons Trompenaars dalamWiraman (2007) mengelompokkan jenis budaya organisasi berdasarkan dua dimensi yaitu; 1) Persamaan hirarki, yaitu suatu kontinum dari adanya persamaan antara anggota organisasi sampai adanya hierarki di anggota organisasi. 2) Orientasi ke orang dan orientasi terhadap tugas, yaitu suatu kontinum dari orientasi ke orang sampai orientasi ketugas. Meskipun sebuah organisasi dapat menampilkan satu tipe budaya organisasi secara menonjol, ia tetap dapat menunjukkan keyakinan normatif dan karakteristik yang lain. Selanjutnya penelitian yang dilakukan oleh Dimas (2016) yang menemukan bahwa budaya organisasi memiliki pengaruh terhadap kinerja keuangan organisasi publik dimana dalam penelitian ini mengatakan bahwa budaya organisasi mengikat karyawan yang bekerja di dalamnya untuk berperilaku sesuai dengan budaya yang ada di dalamnya

Penelitian ini juga mendukung hasil penelitian yang dilakukan oleh beberapa peneliti diantaranya, Mariam (dalam Wales et al., 2017) juga menemukan bahwa budaya 
organisasi dan kepemimpinan secara bersama-sama mempunyai dampak yang signifikan terhadap kinerja karyawan. Faustyna (2015) juga menemukan bahwa budaya organisasi dan dan etos kerja menjadi salah satu faktor yang mempengaruhi kinerja. Dikatakan dalam penelitian ini budaya organisasi dan etos kerja secara bersamasama berdampak positif terhadap kinerja pegawai. Dengan demikian jika budaya organisasi dan etos kerja pada suatu organisasi rendah maka kinerja pegawai di organisasi tersebut juga akan berbanding sama. Selanjutnya penelitian yang dilakukan Sudirjo (2015) yang juga mengemukakan bahwa budaya organisasi, kepemimpinan, dan kepuasan kerja memberikan dampak yang signifikan terhadap kinerja pegawai. Dimana temuan pada penelitian ini mengatakan penurunan budaya organisasi, kepemimpinan, dan kepuasan kerja, komitmen organisasional merupakan penyebab terjadinya kinerja karyawan yang rendah.Baba(2012) juga menemukan bahwa budaya organisasi memberikan pengaruh yang positif terhadap kinerja karyawan. Wales et al(2017) dan Redi (2018) juga menemukan bahwa kinerja karyawan dipengaruhi oleh kepuasan kerja dan budaya organisasi. Selanjutnya penelitian yang dilakukan oleh Hartidah \& Ludigdo (2010) yang menemukan bahwa budaya organisasi hanya memberikan pengaruh terhadap variabel individual. Selanjutnya Priagung(2016) yang menemukan bahwa budaya organisasi memiliki pengaruh terhadap kinerja keuangan organisasi publik. Dimana dalam penelitian ini dikatakan bahwa budaya organisasi mengikat karyawan yang bekerja di dalamnya untuk berperilaku sesuai budaya yang ada di dalamnya.

\section{KESIMPULAN DAN SARAN}

Hasil penelitian dan pembahasan yang telah dikemukakan di atas dapat disimpulkan bahwa variable budaya organisasi, diantaranya inovasi dan pengambilan resiko, orientasi hasil, orientasi orang, orientasi tim, keagresifan, kemantapan/stabilitas baik secara bersama-sama maupun sendiri-sendiri berpengaruh pada kinerja aparatur dalam pengelolaan keuangan di Kabupaten Tanah Datar. Dari hasil uji regresi dapat dilihat bahwa nilai signifikannya dibawah 0,05 , sehingga dapat disimpulkan bahwa Ho ditolak dan Ha diterima. Hasil penelitian ini mendukung penelitian yang sudah dilakukan oleh peneliti dibeberapa tempat pada umumnya menemukan bahwa budaya organisasi berdampak signifikan terhadap kinerja. Sehingga dapat dijelaskan bahwa suatu budaya organisasi akan membentuk suatu komitmen dan konsistensi yang akan membuat anggota organisasi akan termotivasi untuk beradaptasi dengan tuntutan perubahan 
lingkungan yang cenderung berubah-ubah. Sukses atau tidaknya suatu perusahaan atau organisasi berada pada kuat atau tidaknya budaya organisasi, karena kinerja individu anggota dan kinerja perusahaan serta bagaimana senses of belonging karyawan kepada perusahaan atau organisasi tidak akan biasa dipahami dengan baik kecuali memahami budayanya terlebih dahulu.Selanjutnya dari hasil pembahasan serta kesimpulan yang telah dipaparkan di atas penulis dapat memberikan masukan atau saran diantaranya bahwa untuk meningkatkan nilai budaya organisasi karena dari teori-teori yang ada telah dijelaskan bahwa budaya organisasi akan memberikan peningkatan kinerja pegawai jika budaya organisasi dalam kelompok tersebut baik, meskipun nilai pengaruh budaya organisasi terhadap kinerja pengelolaan keuangan nagari di Kabupaten Tanah Datar hanya sebesar 23,3\%. Namun peningkatan budaya organisasi akan baik untuk meningkatkan kinerja aparatur pemerintahan nagari secara keseluruhan. Selain itu,penelitian ini diharapkan dapat membantu penelitilainnya yang akan melakukan penelitian untuk melihat gambaran mengenai pengaruh budaya organisasi terhadap kinerja pengelolaan keuangan nagari terutama di Kabupaten Tanah Datar.

\section{REFERENSI}

Baba, Ali. 2018. Pengaruh Kompetensi, Komunikasi dan Budaya Organisasi terhadap Kinerja Karyawan PT. Semen Bosowa Maros. EKUITAS (Jurnal Ekonomi dan Keuangan). 18 (4). p 524-540.

Edison, Emron, Yohny Anwar, and Imas Komariyah. 2016. Manajemen Sumber Daya Manusia. Bandung: Alfabeta.

Faustyna. 2015. Pengaruh Budaya Organisasi Dan Etos Kerja Terhadap Kinerja Karyawan Pada BPJS Ketenagakerjaan Cabang Belawan. Jurnal Akutansi Dan Bisnis. 1 (2)

Hartidah, A. D., \& Ludigdo, U. 2010. Pengaruh Budaya Organisasi Terhadap Kinerja Auditor pada KAntor Akuntan Publik di Malang dan Surabaya. Jurnal Akuntansi Multiparadigma. 1 (2). $p$ 239-253.

Maabuat, Edward S. 2016. Pengaruh Kepemimpinan, Orientasi Kerja, dan Budaya Organisasi terhadap Kinerja Pegawai (Studi pada Dispenda Sulut UPTD Tondano). Jurnal Berkala Ilmiah Efisiensi. Volume 16 No.01. p 219-231.

Murtiono, Y. 2016. Modul Tata Kelola Keuangan Desa. Yogyakarta: Infest

Peraturan Daerah Kabupaten Tanah Datar No 4 Tahun 2008 tentang Nagari

PeraturanBupati Tanah Datar No 11 Tahun 2014 tentang Pedoman Pengelolaan Keuangan Nagari

Peraturan Mentri Dalam Negri No 113 Tahun 2014 tentang Pengelolaan Keuangan Desa 
Priagung, Dimas Estu. 2016. Pengaruh

Penyerapan Anggaran, Budaya Organisasi dan Kepuasan kerja Dan Pengawasan Inspektorat Terhadap Kinerja Keuangan Organisasi Publik (Studi Pada Pemerintahan Daerah Kabupaten Banjar Negara). Jurnal Ekonomi dan Bisnis Islam. Vol.2,No.1

Rivai, Veithzal dan Deddy Mulyadi. 2013. Kepemimpinan dan Perilaku Organisasi. Jakarta: PT. Raja Grafindo Persada

Sopiah. 2008. Perilaku Organisasi. Yogyakarta. Andi

Syamsir. 2017. Model Pembinaan Kapasitas Aparatur Pemerintahan Nagari Dalam Pengelolaan Keuangan Nagari di Kabupaten Tanah Datar Provinsi Sumatera Barat. Laporan Penelitian. Padang. Universitas Negeri Padang

Tika, Pabundu. 2010. Budaya Organisasi dan Peningkatan Kinerja Perusahaan. Jakarta: PT Bumi Aksara

Trang, Dewi. S. 2013). Gaya kepemimpinan dan budaya organisasi pengaruhnya terhadap kinerja karyawan. Jurnal EMBA: Jurnal Riset Ekonomi, Manajemen, Bisnis Dan Akuntansi, 1(3).

Undang-undang Nomor 32 tahun 2004 tentang Pemerintahan Daerah

Undang-Undang Nomor 6 Tahun 2014 tentang Desa

Wahyu, Andika. 2016. MantanWali Nagari Limo KaumDivonis 1 TahunPenjara. Batusangkar. https://sumbar.antaranews.com/berita/1 77076/mantan-wali-nagari-limo-kaumdivonis-1-tahun-penjara. Antarasumbar

Wales, Gabriela V., Silvya L. Mandey, dan Rudy S. Wenas. 2018. Pengaruh Budaya Organisasi, Gaya Kepemimpinan, dan Disiplin Kerja Terhadap Kinerja Karyawan PT. Bank Tabungan Negara (Persero) Tbk. Kantor Cabang Manado. Jurnal EMBA: Jurnal Riset Ekonomi, Manajemen, Bisnis dan Akuntansi. 5 (3).

Wirawan. 2007. Budaya Dan Iklim Organisasi Teori Aplikasi Dan Penelitian. Jakarta SalembaEmpat

Yudha, Redi Indra, 2018. Pengaruh Budaya Organisasi dan Kepuasan Kerja Terhadap Kinerja Karyawan pada PT. Jaya Abadi Sumber Pasifik Kota Jambi. Manajemen dan Kewirausahaan, 9(2), p 24-35.

PeraturanMentriDalam Negri No 113 Tahun 2014

tentangPengelolaanKeuanganDesa

Dwi. 2017. ProyekJalan Koto Panjang Tanah Datar, DidugaBerbauKorupsi. Batusangkar. http://www.sumbartoday.com/proyekjalan-koto-panjang-tanah-datar-didugaberbau-korupsi.Sumbar Today.

Wahyu, Andika. 2016. MantanWali Nagari Limo KaumDivonis 1 TahunPenjara. Batusangkar. https://sumbar.antaranews.com/berita/1 77076/mantan-wali-nagari-limo-kaumdivonis-1-tahun-penjara. Antarasumbar 